九州大学学術情報リポジトリ

Kyushu University Institutional Repository

Highly Crystallized Tungsten Trioxide Loaded

Titania Composites prepared by Using Ionic Liquids and their Photocatalytic Behaviors

Ezaki, Masato

Department of Nanoscience, Sojo University

Kusakabe, Katsuki

Department of Nanoscience, Sojo University

https://doi.org/10.5109/1495159

出版情報 : Evergreen. 1 (2)，pp.18-24，2014-09. 九州大学グリーンアジア国際リーダー教育センター バージョン：

権利関係 : 


\title{
Highly Crystallized Tungsten Trioxide Loaded Titania Composites prepared by Using Ionic Liquids and their Photocatalytic Behaviors
}

\author{
Masato Ezaki, Katsuki Kusakabe* \\ Department of Nanoscience, Sojo University, 4-22-1 Ikeda, Nishi-ku, Kumamoto 860-0082, Japan \\ *Author to whom correspondence should be addressed, \\ E-mail: kusakabe@nano.sojo-u.ac.jp
}

(Received June 30, 2014; accepted August 6, 2014)

\begin{abstract}
$\mathrm{TiO}_{2} / \mathrm{WO}_{3}$ (Ti-W) photocatalysts were prepared by a simple one-step sol-gel method with 1-butyl-3-methylimidazolium ionic liquids $\left([\mathrm{Bmim}]\left[\mathrm{PF}_{6}\right]\right.$ and $\left.[\mathrm{Bmim}]\left[\mathrm{BF}_{4}\right]\right)$. The mixed sol of $\mathrm{WO}_{3}$ derived from peroxotungstic acid and $\mathrm{TiO}_{2}$ containing ionic liquid was dried and followed by calcination at $800^{\circ} \mathrm{C}$. The resulting Ti-W composite indicated high crystallinity of $\mathrm{WO}_{3}$ and no crystalline transformation of $\mathrm{TiO}_{2}$ from anatase to rutile. $\mathrm{WO}_{3}$ nanoparticles on Ti-W composites $\left(\mathrm{Ti}-\mathrm{W}\left[\mathrm{PF}_{6}\right]\right)$ prepared by using water immiscible $[\mathrm{Bmim}]\left[\mathrm{PF}_{6}\right]$ were highly dispersed due to an emulsification effect. Ti-W[PF 6$]$ indicated the highest reactivity in the photodegradation of methylene blue (MB) under visible light irradiation and the photooxidation of As(III) under UV irradiation.
\end{abstract}

Keywords : Photooxidation, Ionic liquid, Tungsten trioxide, Arsenic, Sol-gel, Titania

\section{Introduction}

Titanium dioxide is well known to indicate an excellent photocatalytic activity under UV irradiation. When $\mathrm{TiO}_{2}$ is utilized in the residential environment such as under daylight and room light conditions, the photocatalytic activity is reduced owing to little absorption in the visible light region. In addition when the level of pollutants is very low, the reaction is controlled by the molecular diffusion of the pollutants toward the photocatalyst and the electron-hole pair created on the $\mathrm{TiO}_{2}$ surface can combine easily, leading to the reduction of photocatalytic activity. Modification of $\mathrm{TiO}_{2}$ photocatalyst is necessary to solve the above disadvantages $^{1,2)}$.

Anatase $\mathrm{TiO}_{2}$ has a band gap of around $3.2 \mathrm{eV}$ and therefore absorbs only 3-4\% of sunlight below $387 \mathrm{~nm}^{3}$. Many research works have been done in preparation of visible light active photocatalysts by doping of nitrogen, carbon or sulfur to $\mathrm{TiO}_{2}{ }^{4-6)}$ and by coupling of $\mathrm{TiO}_{2}$ with active semiconductors to the visible light ${ }^{7)}$. Semiconductor photocatalyst $\mathrm{WO}_{3}$ with a band gap of $2.8 \mathrm{eV}$, corresponding to absorption to approximately $500 \mathrm{~nm}$, has attracted much interest ${ }^{8,9)} \cdot \mathrm{TiO}_{2} / \mathrm{WO}_{3}$ composite is a suitable photocatalyst with visible light absorption due to the stability of these oxides and the absolution positions of their band gap ${ }^{10-12)}$.

Performance of $\mathrm{TiO}_{2} / \mathrm{WO}_{3}$ photocatalyst is considered to be highly dependent on its crystalline structure and the dispersibility of $\mathrm{WO}_{3}$ on $\mathrm{TiO}_{2}$. These properties are strongly affected by calcination temperature. Generation and growth of $\mathrm{WO}_{3}$ crystal are promoted by high calcination temperature. Meanwhile, the crystal transformation of $\mathrm{TiO}_{2}$ from anatase to rutile is also induced at the high temperature. Therefore rutile $\mathrm{TiO}_{2}$ with low catalytic activity as well as crystalline $\mathrm{WO}_{3}$ was formed through high temperature calcination of $\mathrm{TiO}_{2} / \mathrm{WO}_{3}$ precursors. Anatase is more advantageous for photocatalytic reaction because of having highly band gap derived from the unstable crystal structure.

On the other hand, anatase $\mathrm{TiO}_{2}$ as well as amorphous $\mathrm{WO}_{3}$ with low visible light absorption efficiency was formed through low temperature calcination. Accordingly, the preparation of anatase $\mathrm{TiO}_{2}$ and crystalline $\mathrm{WO}_{3}$ composite is desirable for the visible-light sensitive photocatalyst. In the previous paper ${ }^{13)}$, crystalline $\mathrm{WO}_{3}$ nanoparticles were synthesized by acid precipitation and the subsequent calcination at $800^{\circ} \mathrm{C}$ and then added into titania sol. Thus crystalline $\mathrm{TiO}_{2} / \mathrm{WO}_{3}$ composite was obtained from the calcination of the mixed suspension at $400^{\circ} \mathrm{C}$.

Ionic liquid (IL) has attracted much attention for the application in the field of electrochemistry due to their high ionic conductivity and their wide electrochemical potential window ${ }^{14)}$. It has exclusively many attractive properties, including their negligible vapor pressure, chemical stability and non-flammability. Recently, ionic liquids capable of dissolving both organic and inorganic 
species have been widely used as media for organic synthesis, catalytic reaction and sol-gel process ${ }^{15}$. Ionic liquids in sol-gel process are known to act as drying control chemical additives, catalysts, structure directing agents and solvent ${ }^{16-19)}$. Nanostructured $\mathrm{TiO}_{2}$ particles were synthesized via sol-gel method by using 1-butyl-3-methylimidazolium ionic liquid ${ }^{20)}$. The obtained $\mathrm{TiO}_{2}$ particles were thermally stable and thus resistant to the anatase-rutile phase transformation at high calcination temperature. The anatase crystal structure was maintained up to the calcination temperature of $800^{\circ} \mathrm{C}$.

In the present study, a simple one-step sol-gel method with an ionic liquid template was used to prepare a $\mathrm{WO}_{3}$ -loaded titania (Ti-W) photocatalyst. Tungsten was introduced into $\mathrm{TiO}_{2}$ photocatalyst by adding poly tungstic acid precursor solution to a titania sol. The reactivity of Ti-W photocatalysts in liquid phase was investigated on the degradation of methylene blue (MB) and the photooxidation of trivalent arsenic compound both under UV and visible light irradiation ${ }^{21-22)}$.

\section{Experimental}

\subsection{Chemicals and Materials}

Methylene blue (Merck), $\mathrm{NaAsO}_{2}$ (As(III), Wako) and $\mathrm{Na}_{2} \mathrm{HAsO}_{4} \cdot 7 \mathrm{H}_{2} \mathrm{O}(\mathrm{As}(\mathrm{V})$, Wako) were chosen as the model pollutant compound. Titanium tetraisopropoxide (TTIP, Ti-(OCH $\left.\left(\mathrm{CH}_{3}\right)_{2}\right)_{4}$, Tokyo Chemical Industry) and tungstic acid $\left(\mathrm{H}_{2} \mathrm{WO}_{4}\right.$, Sigma-Aldrich) were used as a $\mathrm{TiO}_{2}$ and $\mathrm{WO}_{3}$ sources, respectively. Two types of imidazolium-based ionic liquids, (1-butyl-3methylimidazolium hexafluorophosphate $[\mathrm{Bmim}]\left[\mathrm{PF}_{6}\right]$, and 1-butyl-3-methylimidazolium tetrafluoroborate $[\mathrm{Bmim}]\left[\mathrm{BF}_{4}\right]$, Sigma-Aldrich,), were used for the inhibition of the anatase-rutile phase transformation during calcination. All chemicals were used with no further purification.

Titania sol containing IL was prepared by a sol-gel method based closely on that of Choi et al. ${ }^{20)}$. Titanium tetraisopropoxide was added into ethanol at an EtOH/TTIP molar ratio of 30. IL was then added into the mixture at an IL/TTIP molar ratio of 3 and the mixed solution was vigorously stirred for $10 \mathrm{~min}$. It was observed that the solution became emulsion when water immiscible $[\mathrm{Bmim}]\left[\mathrm{PF}_{6}\right]$ was added. $\mathrm{TiO}_{2}$ powder was obtained from the hydrolysis of TTIP. The resulting sol was also ready for the preparation of Ti-W composite sol.

$5.0 \mathrm{~g}$ of $\mathrm{H}_{2} \mathrm{WO}_{4}$ was dissolved into $30 \mathrm{~mL}$ of aqueous $\mathrm{H}_{2} \mathrm{O}_{2}$ solution $(30 \mathrm{wt} \%$ ) and the obtained solution was completely dried at $50^{\circ} \mathrm{C}$ to obtain peroxotungstic acid powder. The peroxotungstic acid powder was re-dissolved into $5.3 \mathrm{~mL}$ of aqueous EtOH solution (33.3 vol\%). The resulting poly tungstic acid precursor solution and the titania sol containing IL were mixed under stirring for $1 \mathrm{~h}$. Water was slowly added into the mixture, stirred vigorously for $30 \mathrm{~min}$. The yellow precipitate recovered by filtration was washed thoroughly with water and dried at $100^{\circ} \mathrm{C}$ for $2 \mathrm{~h}$. The residual IL and organic compounds were removed from the dried powder by extraction with acetonitrile for $6 \mathrm{~h}$. Then, the powder was recovered again by filtration and washed with acetonitrile and water several times. The resulting Ti-W composite was dried at room temperature for $18 \mathrm{~h}$. The Ti-W composites synthesized by using $[\mathrm{Bmim}]\left[\mathrm{PF}_{6}\right]$ and $[\mathrm{Bmim}]\left[\mathrm{BF}_{4}\right]$ were hereafter abbreviated as Ti-W[PF 6$]$ and Ti-W[BF 4 , respectively.

\subsection{Characterization}

Surface morphology of Ti-W composite was observed and the local-restricted elemental composition was determined using scanning electron microscope and energy dispersive X-ray microanalysis (SEM-EDX, Hitachi S-5200). Absorption spectra of the photocatalysts were obtained with a diffuse reflectance UV-Vis spectrophotometer (JASCO V-600, Japan) equipped with an integrating sphere and were converted from reflection to absorbance by the Kubelka-Munk method. BET-specific surface area and the mean porous equivalent diameter were determined using a micrometrics automatic surface area analyzer and a porosimetry system (TriStar 3000, Shimadzu). A powder X-ray diffraction pattern (XRD) was obtained using an $\mathrm{XRD}$ diffractometer (Rigaku, $\mathrm{Cu}-\mathrm{Ka}$ radiation) to examine the crystal structure of titania and tungsten trioxide.

\subsection{Photocatalytic measurement}

Photodegradation of MB is the most popular method for the evaluation of photocatalytic performance ${ }^{21)}$. The photodegradation was conducted in a $100 \mathrm{~mL}$ quartz beaker with a suspension containing $50 \mathrm{~mL}$ of 25 mmol $\mathrm{m}^{-3} \mathrm{MB}$ aqueous solution and $20 \mathrm{mg}$ photocatalyst. The initial $\mathrm{pH}$ value of the solution was fixed at 3 . The suspension was agitated in darkness and then irradiated from underneath using a UV lamp $(9.0 \mathrm{~W}, \lambda \max =365$ $\mathrm{nm}$ ) for UV irradiation and a lamp of projector (EPSON EB-1750, $230 \mathrm{~W}$ lamp, $2600 \mathrm{~lm}$ ) for visible light irradiation. The distance between the light source and the beaker bottom was $10 \mathrm{~mm}$. The concentration of $\mathrm{MB}$ was estimated by measuring the absorbance at $665 \mathrm{~nm}$ using a UV-Vis spectrophotometer. The adsorption amounts of MB on the photocatalysts were evaluated in darkness using the same experimental apparatus.

$\mathrm{TiO}_{2}$ is well known adsorbent for the arsenic compounds. To evaluate the photo-reactivity of Ti-W photocatalyst, the photooxidation of As(III) was investigated with the same experimental procedures as described for the photodegradation of MB. The initial concentration of As(III) was fixed at $250 \mathrm{mmol} \mathrm{m}^{-3}$. The concentrations of arsenic compounds were determined from the absorbance at $195 \mathrm{~nm}$ using HPLC equipped with a UV detector (TOSOH, 8020 series). 


\section{Results and discussion}

\subsection{Catalyst characterization}

The absorption of visible light on Ti-W composites with the tungsten content of $30 \mathrm{wt} \%$ was found to be significantly strong compared to the composites with the tungsten content of 10 and $20 \mathrm{wt} \%$ Hereafter, the tungsten content in Ti-W composite was fixed at $30 \mathrm{wt} \%$. Fig. 1 shows the powder XRD patterns of $\mathrm{TiO}_{2}$ and Ti-W composites synthesized at the calcination temperature of $800^{\circ} \mathrm{C}$. $\mathrm{TiO}_{2}$ and $\mathrm{Ti}-\mathrm{W}$ composites synthesized without IL ((a) and (b) in Fig. 1) exhibit both anatase and rutile peaks at $25.3^{\circ}$ and $27.4^{\circ}$, respectively. This means the crystal phase transformation from anatase to rutile occurred at $800^{\circ} \mathrm{C}$. Well defined three peaks around $24^{\circ}$ corresponding to monoclinic $\mathrm{WO}_{3}$ were clearly identified in any Ti-W compounds calcinated at $800^{\circ} \mathrm{C}$. However no rutile peak was observed in Ti-W[PF 6$]$ and Ti-W[BF 4 ((c) and (d) in Fig. 1). The $\mathrm{TiO}_{2}$ inorganic network formed in sol-gel synthesis is not thermally stable enough to resist anatase-rutile crystal phase transformation during thermal treatment ${ }^{23}$. Owing to high thermal stability and high ion density of dispersed IL in $\mathrm{TiO}_{2}$ sol-gel network, highly porous and thermally stable $\mathrm{TiO}_{2}$ particles with anatase crystalline structure were formed at $800^{\circ} \mathrm{C}^{20)}$. Although the $\mathrm{WO}_{3}$ crystallization in Ti-W composites proceeded with increase in calcination temperature, the anatase-rutile

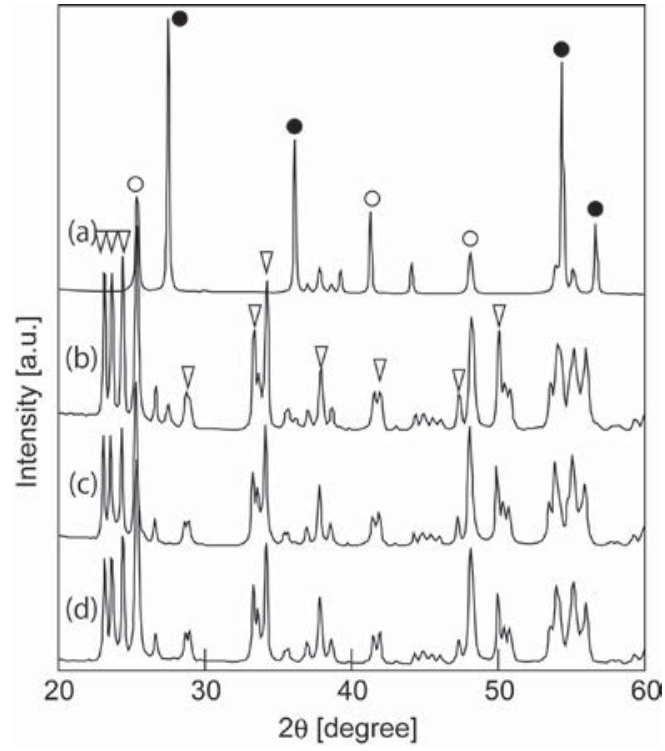

Fig. 1 XRD patterns of $\mathrm{TiO}_{2}$ and $\mathrm{Ti}-\mathrm{W}$ compounds, (a) $\mathrm{TiO}_{2}$ synthesized without IL, (b) Ti-W compound synthesized without IL, (c) Ti-W[PF 6$]$, (d) Ti-W[BF $]$, O; anatase $\mathrm{TiO}_{2}, \bullet$; rutile $\mathrm{TiO}_{2}, \forall$ : tungsten trioxide, calcination temperature $=800{ }^{\circ} \mathrm{C}$.

phase transformation started above $800^{\circ} \mathrm{C}$. Accordingly, the calcination temperature was fixed at $800^{\circ} \mathrm{C}$.

Table 1 Characterization of Ti-W composites (30 wt $\left.\% \mathrm{WO}_{3}-\mathrm{TiO}_{2}\right)$.

\begin{tabular}{|c|c|c|c|c|c|c|c|}
\hline $\begin{array}{l}\text { Synthesis } \\
\text { condition }\end{array}$ & $\begin{array}{l}\text { Calcination } \\
\text { temp. }\left({ }^{\circ} \mathrm{C}\right)\end{array}$ & $\begin{array}{c}\text { Crystal phase } \\
\mathrm{TiO}_{2} / \mathrm{WO}_{3}\end{array}$ & $\begin{array}{c}\text { Pore } \\
\text { volume } \\
\left(\mathrm{cm}^{3} \cdot \mathrm{g}^{-1}\right)\end{array}$ & $\begin{array}{c}\text { BET surface } \\
\text { area } \\
\left(\mathrm{m}^{2} \cdot \mathrm{g}^{-1}\right)\end{array}$ & $\begin{array}{l}D_{B J H} \\
(\mathrm{~nm})\end{array}$ & $\begin{array}{c}C S_{X R D} \\
(\mathrm{~nm}) \\
\mathrm{TiO}_{2} / \mathrm{WO}_{3}\end{array}$ & $\begin{array}{l}P S_{D L S} \\
(\mathrm{~nm})\end{array}$ \\
\hline \multirow{5}{*}{$\begin{array}{c}\text { Ti-W } \\
\text { without IL }\end{array}$} & as-synthesized & Amor. ${ }^{* 1} /$ & 0.116 & 151 & 7.04 & - & \\
\hline & & Amor. & & & & & \\
\hline & 400 & A. ${ }^{* 2} /$ Amor. & 0.168 & 142 & 5.5 & $15.9 /-$ & \\
\hline & 800 & A. and & 0.057 & 17.1 & 26.1 & $32.0 /$ & 389.5 \\
\hline & & $\mathrm{R}^{* 3} /$ Mono. $^{* 4}$ & & & & 46.5 & \\
\hline \multirow[t]{3}{*}{$\mathrm{Ti}-\mathrm{W}\left[\mathrm{PF}_{6}\right]$} & as-synthesized & A./Amor. & 0.15 & 24.65 & - & 4.62 & \\
\hline & 400 & A./Amor. & 0.14 & 163 & 4.10 & 16.5 & \\
\hline & 800 & A./Mono. & 0.08 & 16.6 & 26.6 & $31.4 / 45.5$ & 274.0 \\
\hline \multirow[t]{3}{*}{$\mathrm{Ti}-\mathrm{W}\left[\mathrm{BF}_{4}\right]$} & as-synthesized & Amor./Amor. & - & 0.09 & - & - & \\
\hline & 400 & A./Amor. & 0.12 & 122 & 3.93 & 6.61 & \\
\hline & 800 & A./Mono. & 0.04 & 10.53 & 42.66 & $41.8 / 57.6$ & 173.5 \\
\hline
\end{tabular}

*1, Amor.=amorphous, $* 2, \mathrm{~A} .=$ anatase, $* 3, \mathrm{R} .=$ rutile, $* 4$, Mon. $=$ Monoclinic $; V D_{B J H}, \mathrm{BJH}$ average pore diameter;

$C S_{X R D}$, crystallite size measured from XRD; $P S$, particle size measured from DLS. 

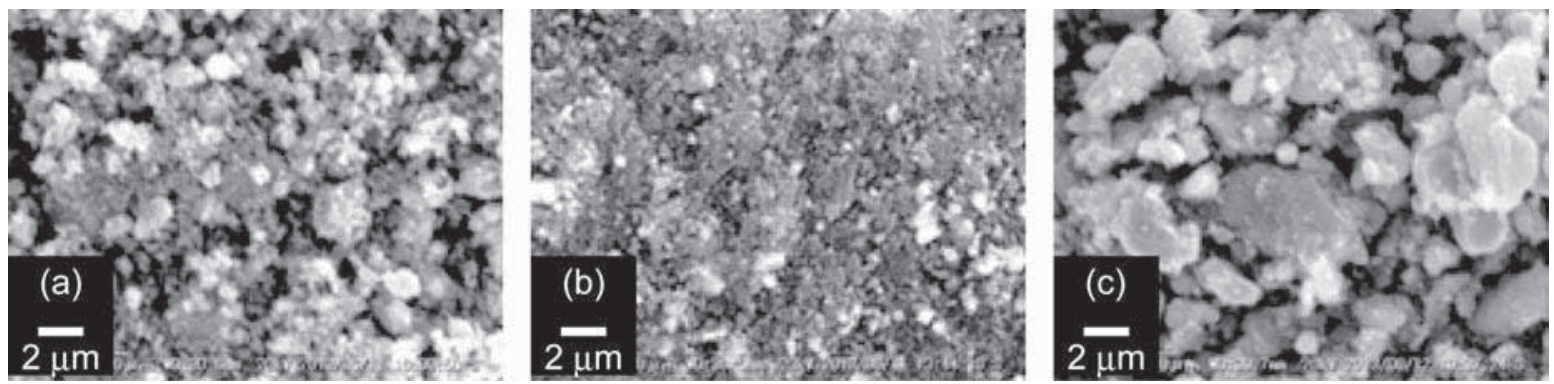

Fig. 2 SEM image of Ti-W compounds, (a): without IL, (b): Ti-W[PF $]$, (c): Ti-W[BF 4 .

Table 1 summarizes the pore volume, BET-specific surface area, average pore diameter and crystalline size of the synthesized Ti-W compounds. Ti-W[PF 6 indicated higher porosity and lower crystalline size than $\mathrm{Ti}-\mathrm{W}\left[\mathrm{BF}_{4}\right]$. Water-miscible $[\mathrm{Bmim}]\left[\mathrm{BF}_{4}\right]$ might influenced the increase in mesopore size. However the agglomeration size determined with dynamic light scattering became small when $[\mathrm{Bmim}]\left[\mathrm{BF}_{4}\right]$ was used.

Fig. 2 shows surface morphology of Ti-W compounds. Fine powder was obtained for Ti-W[ $\left.\mathrm{PF}_{6}\right]$ compared to Ti-W compounds prepared without IL and Ti-W[BF $\left.\mathrm{BF}_{4}\right]$ due to the formation of fine aqueous droplets in emulsion. From the SEM-EDX analysis, homogeneous distribution of $\mathrm{WO}_{3}$ on Ti-W[PF 6 powder was confirmed.

Fig. 3 shows the diffuse reflectance spectrophotometry of Ti-W composites. For the comparison, the spectra of anatase $\mathrm{TiO}_{2}$ and $\mathrm{WO}_{3}$ powders were also indicated. Absorption in visible region is caused by the modification of $\mathrm{TiO}_{2}$ with $\mathrm{WO}_{3}$. However, low absorption of visible light was observed for Ti-W[PF 6 at the calcination temperature of $400^{\circ} \mathrm{C}$ ((a) in Fig. 3) due

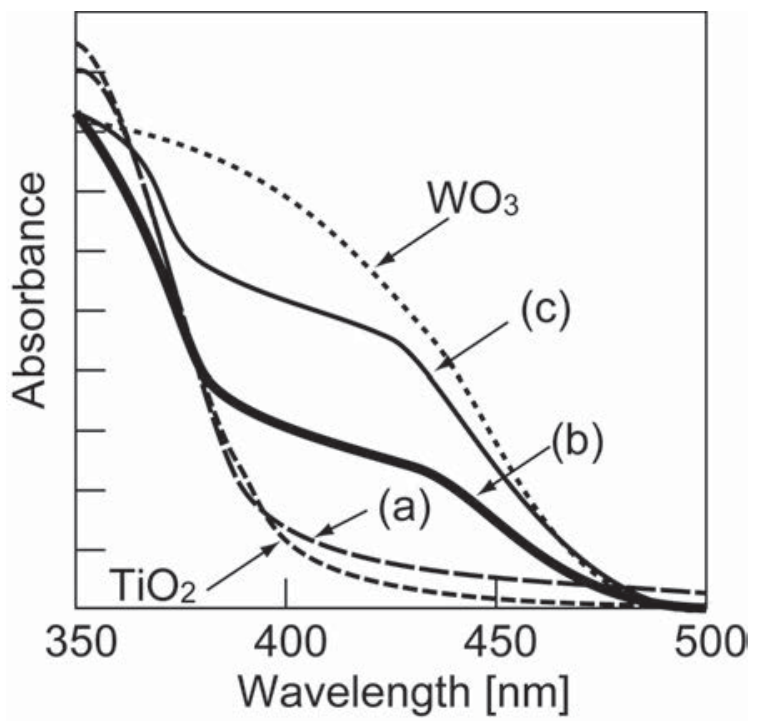

Fig. 3 Diffuse reflectance spectra of Ti-W compounds,

(a) $\mathrm{Ti}-\mathrm{W}\left[\mathrm{PF}_{6}\right]$ at $400^{\circ} \mathrm{C}$, (b) $\mathrm{Ti}-\mathrm{W}\left[\mathrm{PF}_{6}\right]$ at $800^{\circ} \mathrm{C}$,

(c) $\mathrm{Ti}-\mathrm{W}\left[\mathrm{BF}_{4}\right]$ at $800^{\circ} \mathrm{C}$.

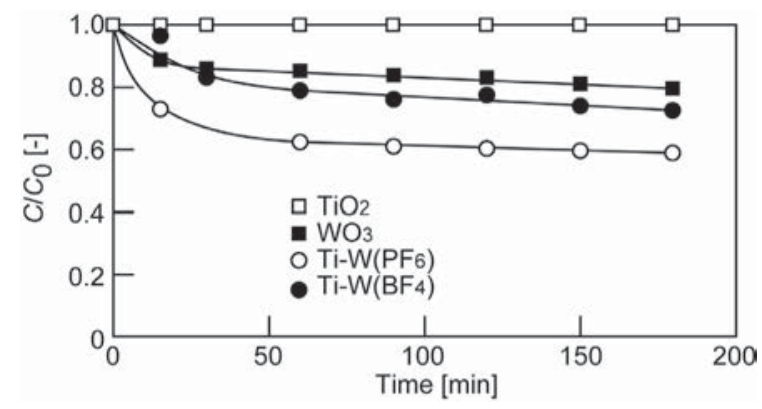

Fig.4 Adsorption of $\mathrm{MB}$ on $\mathrm{TiO}_{2}(\square), \mathrm{WO}_{3}(\square)$, $\mathrm{Ti}-\mathrm{W}\left[\mathrm{PF}_{6}\right](\mathrm{O})$ and Ti-W[BF 4$](\bullet)$.

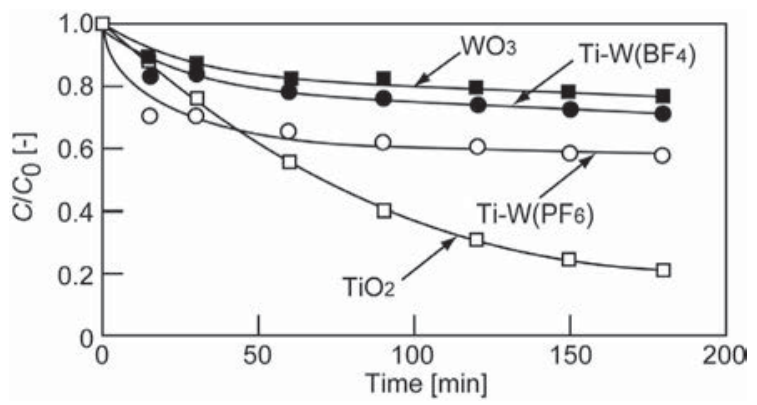

Fig.5 Photodegradation behavior of MB on Ti-W compounds under UV irradiation; $\mathrm{TiO}_{2}(\square)$, $\mathrm{WO}_{3}(\boldsymbol{\square}), \mathrm{Ti}-\mathrm{W}\left[\mathrm{PF}_{6}\right](\mathrm{O})$ and $\mathrm{Ti}-\mathrm{W}\left[\mathrm{BF}_{4}\right](\bullet)$.

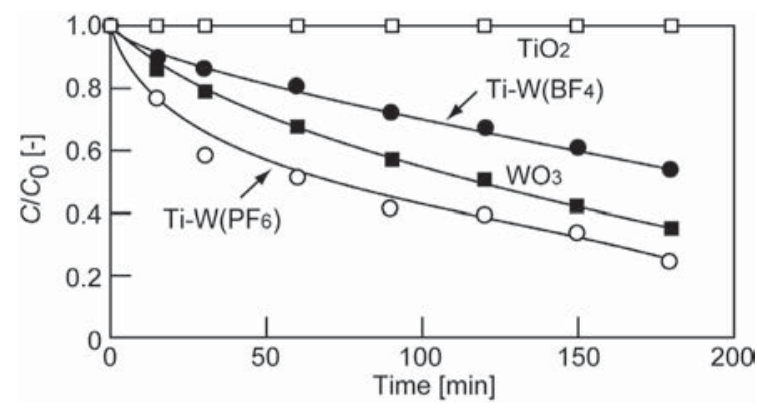

Fig. 6 Photodegradation behavior of MB on Ti-W compound under visible light irradiation; $\mathrm{TiO}_{2}$ $(\square), \mathrm{WO}_{3}(\boldsymbol{\square}), \mathrm{Ti}-\mathrm{W}\left[\mathrm{PF}_{6}\right](\mathrm{O})$ and $\mathrm{Ti}-\mathrm{W}\left[\mathrm{BF}_{4}\right]$ $(\bullet)$. 
to the insufficient crystallinity of $\mathrm{WO}_{3}$. Although there was little difference in crystallinity between $\mathrm{Ti}-\mathrm{W}\left[\mathrm{BF}_{4}\right]$ and $\mathrm{Ti}-\mathrm{W}\left[\mathrm{PF}_{6}\right]$ at the calcination temperature of $800^{\circ} \mathrm{C}$ as shown in Fig. 1, Ti-W[BF $\left.\mathrm{BF}_{4}\right]$ with lower agglomeration size had better property than $\mathrm{Ti}-\mathrm{W}\left[\mathrm{PF}_{6}\right]$ as regarding the visible light absorption.

\subsection{Photodegradation of methylene blue}

Fig. 4 shows the adsorption behavior of $\mathrm{MB}$ on $\mathrm{TiO}_{2}$, $\mathrm{WO}_{3}, \mathrm{Ti}-\mathrm{W}\left[\mathrm{PF}_{6}\right]$ and $\mathrm{Ti}-\mathrm{W}\left[\mathrm{BF}_{4}\right]$. There was no adsorption of $\mathrm{MB}$ on $\mathrm{TiO}_{2}$ prepared by a sol-gel method 24). The negative charged surface of $\mathrm{WO}_{3}$ enhanced the adsorption of cationic MB. In addition, higher adsorption amount of MB was observed on Ti-W composites with high crystallinity compared to $\mathrm{WO}_{3}$ powder calcinated at $800^{\circ} \mathrm{C}$. Higher adsorption amount of $\mathrm{MB}$ was observed on $\mathrm{Ti}-\mathrm{W}\left[\mathrm{PF}_{6}\right]$ of the well dispersed $\mathrm{WO}_{3}$ with BET surface area of $16.6 \mathrm{~m}^{2} \mathrm{~g}^{-1}$ compared to $\mathrm{Ti}-\mathrm{W}\left[\mathrm{BF}_{4}\right]$ powder with BET surface area of $10.5 \mathrm{~m}^{2} \cdot \mathrm{g}^{-1}$. The adsorption amount of $\mathrm{MB}$ on $\mathrm{Ti}-\mathrm{W}\left[\mathrm{PF}_{6}\right]$ reached to 200 $\mathrm{mg}^{-1} \mathrm{~g}^{-1}$ under the condition of saturated adsorption.

Fig. 5 shows the photodegradation behavior of $\mathrm{MB}$ on $\mathrm{TiO}_{2}, \quad \mathrm{WO}_{3}, \mathrm{Ti}-\mathrm{W}\left[\mathrm{PF}_{6}\right]$ and Ti-W[BF 4$]$ under UV irradiation. The photodegradation behavior of $\mathrm{MB}$ on $\mathrm{TiO}_{2}$ was clearly observed under UV irradiation. In this experiment, simultaneous adsorption and photodegradation of $\mathrm{MB}$ occurred on $\mathrm{WO}_{3}$ nanoparticles. As might be expected, the $\mathrm{WO}_{3}$ itself had no photocatalytic activity to $\mathrm{MB}$ degradation. The changes in $\mathrm{MB}$ concentration for $\mathrm{Ti}-\mathrm{W}\left[\mathrm{PF}_{6}\right]$ and $\mathrm{Ti}-\mathrm{W}\left[\mathrm{BF}_{4}\right]$ in Fig. 5 were almost same as those by adsorption of $\mathrm{MB}$ in Fig. 4. Thus the photodegradation rate of $\mathrm{MB}$ for $\mathrm{Ti}-\mathrm{W}\left[\mathrm{PF}_{6}\right]$ and $\mathrm{Ti}-\mathrm{W}\left[\mathrm{BF}_{4}\right]$ were found to be very low under UV irradiation, which might be caused by a mismatch between the site for the photocatalytic reaction on $\mathrm{TiO}_{2}$ and that for the adsorption on $\mathrm{WO}_{3}$.

Photodegradation behavior of $\mathrm{MB}$ under visible light irradiation was drastically changed compared with those under UV irradiation as shown in Fig. 6. The $\mathrm{TiO}_{2}$ itself indicated no photodegradation of $\mathrm{MB}$ because of no absorption of visible light. Meanwhile photodegradation rate of $\mathrm{MB}$ on $\mathrm{WO}_{3}, \mathrm{Ti}-\mathrm{W}\left[\mathrm{PF}_{6}\right]$ and Ti-W[BF 4$]$ under visible light irradiation were much improved by combination effect of high adsorption of $\mathrm{MB}$ on the $\mathrm{WO}_{3}$ surface and their ability to absorption of visible light. Although Ti-W[BF $\left.\mathrm{BF}_{4}\right]$ had higher ability to absorb visible light than Ti-W[PF 6 , Ti-W[PF 6 indicated higher photocatalytic activity for $\mathrm{MB}$ decomposition due to the high dispersive $\mathrm{WO}_{3}$ nanoparticles.

\subsection{Photooxidation of As(III)}

Fig. 7 shows the adsorption behavior of As(III) and $\mathrm{As}(\mathrm{V})$ on the photocatalysts. $\mathrm{WO}_{3}$ itself exhibited weakly adsorption of $\mathrm{As}(\mathrm{III})$ and no adsorption of $\mathrm{As}(\mathrm{V})$. As(V) adsorption on sol-gel synthesized $\mathrm{TiO}_{2}$ was very much higher than $\mathrm{As}(\mathrm{III})$ adsorption at $\mathrm{pH}$ 3. Similar behaviors for adsorption of $\mathrm{As}(\mathrm{III})$ and $\mathrm{As}(\mathrm{V})$ on the $\mathrm{TiO}_{2}$ prepared by hydrolysis of titanium sulfate and the commercial

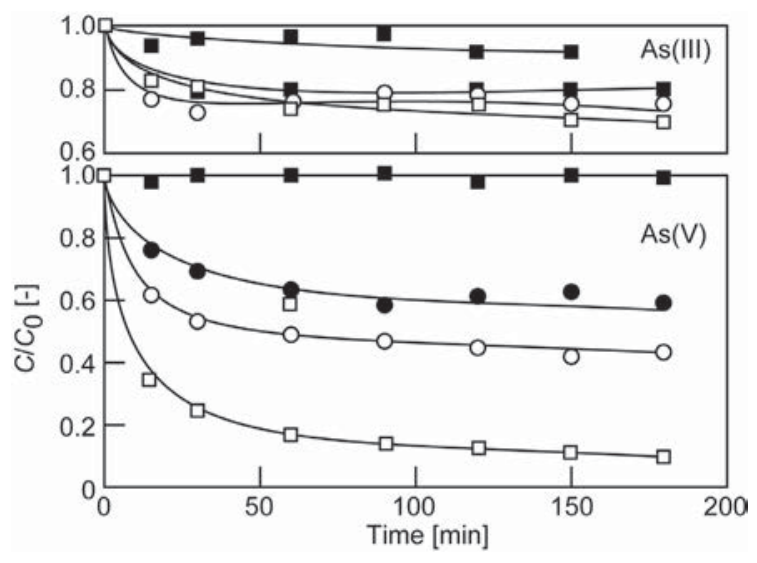

Fig. 7 Adsorption of $\mathrm{As}(\mathrm{III})$ and $\mathrm{As}(\mathrm{V}) ; \mathrm{TiO}_{2}(\square)$, $\mathrm{WO}_{3}(\mathbf{\square})$, Ti-W[PF 6$](\mathrm{O})$ and Ti-W[BF 4$](\bullet)$, concentration of As(III): $250 \mathrm{mmolm}^{-3}$, concentration of As (V): $250 \mathrm{mmolm}^{-3}, \mathrm{pH} 3$.

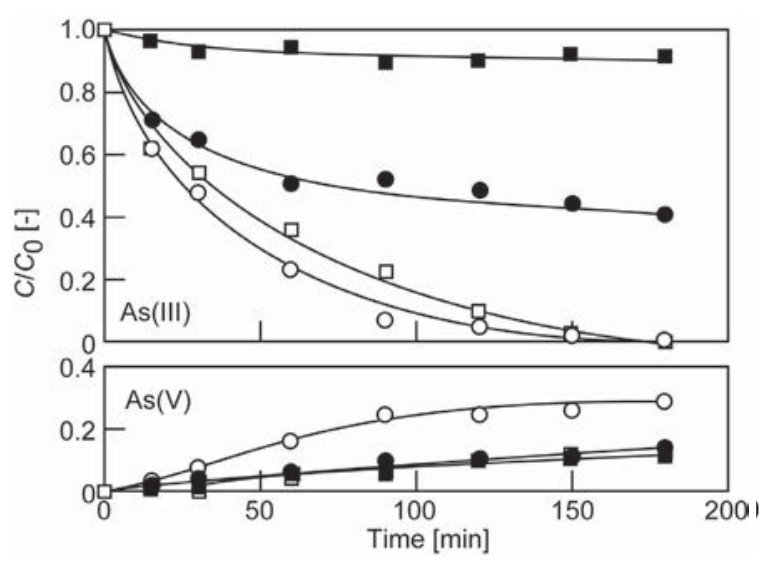

Fig. 8 Photooxidation of $\mathrm{As}(\mathrm{III})$ on Ti-W under UV irradiation; $\mathrm{TiO}_{2}(\square), \mathrm{WO}_{3}(\square)$, Ti-W[PF 6$](\mathrm{O})$ and $\mathrm{Ti}-\mathrm{W}\left[\mathrm{BF}_{4}\right](\bullet)$, concentration of $\mathrm{As}(\mathrm{III}): 250$ $\mathrm{mmolm}^{-3}, \mathrm{pH} 3$.

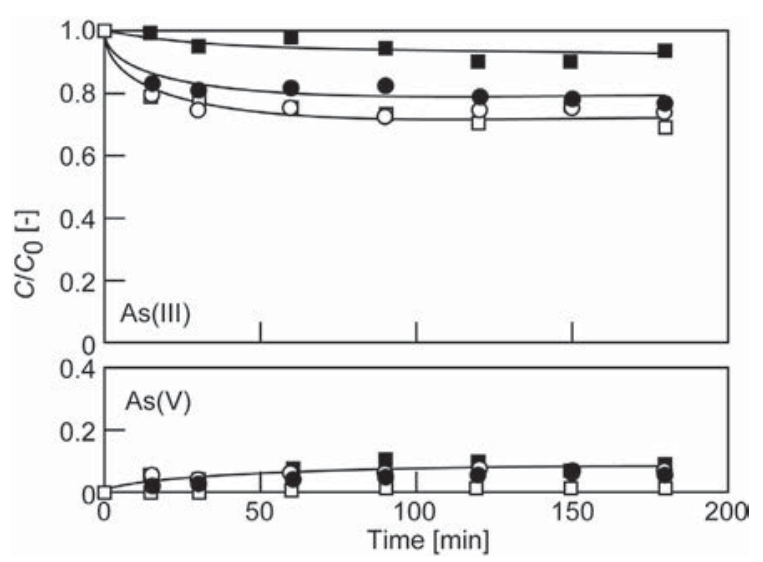

Fig. 9 Photodegradation of As(III) on Ti-W under visible light irradiation; $\mathrm{TiO}_{2}(\square), \mathrm{WO}_{3}(\mathbf{\square}), \mathrm{Ti}-\mathrm{W}\left[\mathrm{PF}_{6}\right]$ (O) and $\mathrm{Ti}-\mathrm{W}\left[\mathrm{BF}_{4}\right](\bullet)$, concentration of $\mathrm{As}(\mathrm{III})$ : $250 \mathrm{mmolm}^{-3}, \mathrm{pH} 3$. 
$\mathrm{TiO}_{2}$ have been reported ${ }^{25,26)}$.

$\mathrm{TiO}_{2}$ photocatalyst has been shown to effective in oxidizing $\mathrm{As}(\mathrm{III})$ to $\mathrm{As}(\mathrm{V})^{27-30)}$. Photooxidation of $\mathrm{As}(\mathrm{III})$ on $\mathrm{TiO}_{2}$ proceeds predominantly by reaction of $\mathrm{As}(\mathrm{III})$ with a superoxide radical or hydroxyl radical $^{27,28)}$ (reactions 1 and 2). The resulting As(IV) is expected to be quickly oxidized to As(V) even by molecular oxygen (reaction 3).

$$
\begin{aligned}
& \mathrm{As}(\mathrm{III})+\mathrm{O}_{2}^{\cdot-}+2 \mathrm{H}+\rightarrow \mathrm{As}(\mathrm{IV})+\mathrm{HO}_{2}{ }^{-} \\
& \mathrm{As}(\mathrm{III})+\mathrm{OH}^{\cdot} \rightarrow \mathrm{As}(\mathrm{IV})+\mathrm{OH}^{-} \\
& \mathrm{As}(\mathrm{IV})+\mathrm{O}_{2} \rightarrow \mathrm{As}(\mathrm{V})+\mathrm{O}_{2}^{\cdot-}
\end{aligned}
$$

As shown in Fig. 8, As(III) concentration for $\mathrm{Ti}-\mathrm{W}\left[\mathrm{PF}_{6}\right]$ as well as $\mathrm{TiO}_{2}$ was rapidly decreased to zero level after 3 hours under UV irradiation. Oxidized As(V) was successively adsorbed on the surface of $\mathrm{TiO}_{2}$ and then the residual free $\mathrm{As}(\mathrm{V})$ in the solution was able to be detected. High photooxidation ability of $\mathrm{As}(\mathrm{III})$ on Ti-W[PF 6 would be caused by the effective charge separation and prevention of recombination of the electron-hole pair.

As shown in Fig. 9, Ti-W $\left[\mathrm{PF}_{6}\right]$ which was suitable as photocatalyst under UV irradiation exhibited a poor response to visible light for As(III) oxidation. There was no detection of $\mathrm{As}(\mathrm{V})$ in darkness during the adsorption test. However, a slight increase in $\mathrm{As}(\mathrm{V})$ concentration suggests the photooxidation of $\mathrm{As}(\mathrm{III})$ on $\mathrm{Ti}-\mathrm{W}\left[\mathrm{PF}_{6}\right]$ proceeds under visible light irradiation.

\section{Conclusions}

Highly dispersed Ti-W composite (Ti-W[PF 6$]$ ) was successfully prepared by a simple one-step sol-gel method with ionic liquid $\left([\mathrm{Bmim}]\left[\mathrm{PF}_{6}\right]\right)$. The resulting Ti-W composites indicated high crystallinity of $\mathrm{WO}_{3}$ and no crystalline transformation of $\mathrm{TiO}_{2}$ from anatase to rutile with the assistance of IL. The combination of $\mathrm{WO}_{3}$ and $\mathrm{TiO}_{2}$ showed excellent properties to the visible light absorption. Photocatalytic activities of $\mathrm{TiO}_{2}, \mathrm{WO}_{3}$ and Ti-W photocatalysts were evaluated from photodegradation of methylene blue (MB) and photooxidation of As(III) both under UV and visible light irradiation. The Ti-W composites were ineffective for the degradation of MB under UV irradiation, which arose from a mismatch between the site for the photocatalytic reaction on $\mathrm{TiO}_{2}$ and that for the adsorption on $\mathrm{WO}_{3}$. Meanwhile, Ti-W[PF 6$]$ indicated the highest photocatalytic activity in both the photodegradation of $\mathrm{MB}$ under visible light irradiation and the photooxidation of As(III) under UV irradiation.

\section{Acknowledgement}

This work was supported by a JSPS Grant-in-Aid for Challenging Exploratory Research (25630359), Japan.

\section{References}

1) R. Daghrir, P. Drogui and D. Robert, Ind. Eng. Chem. Res., 52, 3581 (2013).

2) M. Pelaez, N.T. Nolan, S.C. Pillai, M.K. Seery, P. Falaras, A.G. Kontos, P.S.M. Dunlop, J.W.J. Hamilton, J.A. Byrne and K. O'Shea, Appl. Catal. B: Environ., 125, 331 (2012).

3) H. Tong, S. Quyang, Y. Bi, N. Umezawa, M. Oshikiri and J. Ye, Adv. Mater., 24, 229 (2012).

4) H. Shen, L. Mi, P. Xu, W. Shen and P.-N. Wang, Appl. Surf. Sci., 253, 7024 (2007).

5) M. Shen, Z. Wu, H. Huang, Y. Du, Z. Zou, P. Yang, Mater. Lett., 60, 693-697 (2006).

6) D.Way, L. Xiao, Q. Luo, X. Li, J. An and Y. Duan, J. Hazard. Mater., 192, 150 (2011).

7) M. Fujishima, Q. Jin, H. Yamamoto, H. Tada and M. Nolan, Phys. Chem. Chem. Phys., 14, 705 (2012).

8) T.-Y. Ma, Z.-Y. Yuan and J.-L. Cao, Eur. J. Inorg. Chem., 716 (2010).

9) K. Maeda, M. Higashi, D. Liu, R. Abe and K. Domen, JACS, 132, 5858 (2010).

10) Saepurahman, M.A. Abdullh and F.K. Chong, J. Hazard. Mater., 176, 451 (2010).

11) S.A.K. Leghari, S. Sajjad, F. Chen and J. Zhang, Chem. Eng. J., 166, 906 (2011).

12) S.A. Singh and G. Madras, Sep. Purif. Technol., 105, 79 (2013).

13) M. Ezaki, W. Michida, K. Kusakabe, Adv. Mater. Res., in press, (2014).

14) P. Hapiot and C. Lagrost, Chem. Rev., 108, 2238 (2008).

15) D. Bradley, P. Dyson and T. Welton, Chem. Rev., 9, 18 (2000).

16) A. Vioux, L. Viau, S. Volland and J. Le Bideau, C.R. Chimie, 13, 242 (2010).

17) L. Wang, S.-Z. Xu, H.-J. Li, L.-X. Chang, Zhi-Su, M.-H. Zeng, L.-N. Wang and Y.-N. Huang, Journal of Solid State Chemistry 184, 720 (2011).

18) L. Wang, L. Chang, B. Zhao, Z. Yuan, G. Shao and W. Zheng, Inorganic Chemistry, 47, 1443 (2008).

19) Li Wang, Li-Xian Chang, Lian-Qiang Wei, Shen-Zhi Xu, Ming-Hua Zeng and Shi-Lie Pan, J. Mater. Chem., 21, 15732 (2011).

20) H. Choi, Y.J. Kim, R.S. Varma and D.D. Dionysiou, Chem. Mater., 18, 5377 (2006). 
21) R.J. Tayade, T.S. Natarajan and H.C. Bajaj, Ind. Eng. Chem. Res., 48, 10262 (2009).

22) M. Ferguson, M. Hoffmann and J. Hering, Environ. Sci. Technol., 39, 1880 (2005).

23) F. Bosc, A. Ayral, P.-A. Albouy, L. Datas and C. Guizard, Chem Mater., 16, 2208 (2004).

24) K. Kusakabe, M. Ezaki, A. Sakoguchi, K. Oda and N. Ikeda, Chem. Eng. J., 180, 245 (2012).

25) P.K. Dutta, A.K. Ray, V.K. Sharma and F.J. Millero, J. Colloid Interf. Sci., 278, 270 (2004).

26) M. Pena, X. Meng, G.P. Korfiatis and C. Jing, Environ. Sci. Technol., 40, 1257 (2006).

27) H. Yang, W.-Y. Lin and K. Rajeshwar, J. Photoch. Photobio. A, 123, 69 (1999).

28) M.A. Ferguson, M.R. Hoffmann and J.G. Hering, Environ. Sci. Technol., 39, 1880 (2005).

29) P.K. Dutta, S.O. Pehkonen, V.K. Sharma and A.K. Ray, Environ. Sci. Technol., 39, 1827 (2005).

30) J. Ryu and W. Choi, Environ. Sci. Technol., 40, 7034 (2006). 